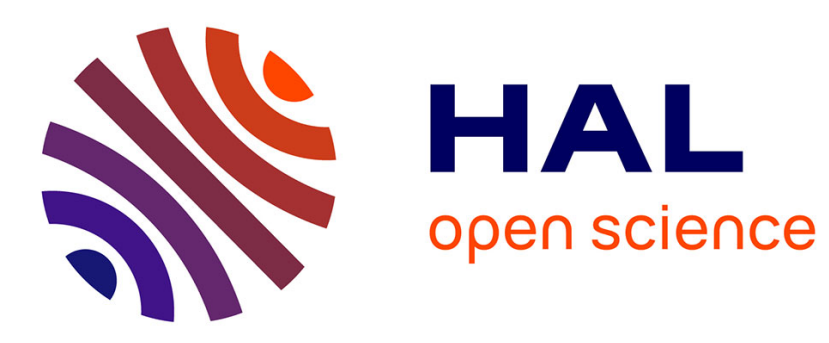

\title{
Climate impact and energy sustainability of future European neighborhoods
}

Louis Delannoy, Salil Puri, A. T D Perera, Silvia Coccolo, Dasaraden Mauree, Jean-Louis Scartezzini

\section{- To cite this version:}

Louis Delannoy, Salil Puri, A. T D Perera, Silvia Coccolo, Dasaraden Mauree, et al.. Climate impact and energy sustainability of future European neighborhoods. 2018 5th International Symposium on Environment-Friendly Energies and Applications (EFEA), Sep 2018, Rome, France. 10.1109/EFEA.2018.8617066 . hal-03159380

\section{HAL Id: hal-03159380 \\ https://hal.science/hal-03159380}

Submitted on 21 Apr 2021

HAL is a multi-disciplinary open access archive for the deposit and dissemination of scientific research documents, whether they are published or not. The documents may come from teaching and research institutions in France or abroad, or from public or private research centers.
L'archive ouverte pluridisciplinaire HAL, est destinée au dépôt et à la diffusion de documents scientifiques de niveau recherche, publiés ou non, émanant des établissements d'enseignement et de recherche français ou étrangers, des laboratoires publics ou privés. 


\title{
Climate impact and energy sustainability of future European neighborhoods
}

\author{
Louis Delannoy, Salil Puri, A.T.D. Perera*, Silvia Coccolo, Dasaraden Mauree, Jean-Louis Scartezzini \\ Solar Energy and Building Physics Laboratory (LESO-PB) \\ Ecole Polytechnique Fédérale de Lausanne (EPFL), CH-1015 Lausanne, Switzerland \\ *Corresponding author: dasun.perera@epfl.ch
}

\begin{abstract}
This study presents a comprehensive analysis of typical European city centers energy demand and supply for present time and 2050, according to the Intergovernmental Panel for Climate Change (IPCC) climatic scenario A1B. Two multifamily houses are modeled, adapted and simulated considering local thermal characteristics and climate conditions of twentytwo European countries. An energy hub system is optimized in order to investigate how the micro-grid responds to the renewable energy integration for ten countries. The European heating demand is evaluated to be reduced by half by $2050(49 \%)$ due to the climate change $(6 \%)$ and refurbishment $(43 \%)$ effects. Integration of renewable energy sources in most European countries is set to surpass the $\mathbf{E U}$ renewable energy targets given proper implementation of appropriate governmental polices coupled with emerging technological advancements in the renewable energy sector.
\end{abstract}

Keywords-urban energy systems; energy efficiency; renewable energy integration; energy supply optimization

\section{INTRODUCTION}

Climate change, temperature increase, demographic explosion aligned with the scarcity of our raw resources and the decrease in biodiversity threatens our society model. This so called Grand Challenge [1] forces many countries to develop an alternative attitude paving the way towards a sustainable future. Being responsible for $60 \%$ of world greenhouse gas emissions and $78 \%$ of its total energy consumption while they cover less than two percent of the Earth's surface [2], cities are primary actors of climate change. Driven by the exponential growth of urban population [3], urban energy management is a priority to ensure a proper transition of our energy model. More precisely, three key drivers are pivotal: energy efficiency, renewable energy integration and smart energy management [4].

Integrated energy systems such as energy hub [5] [6] [7] are promising prospects to integrate renewables for small urban areas and villages. And while European policy makers are seeking ways to address energy transition to large urban areas and respect their planned country specific targets [8], an extension of such system shall serve them as a basis to compare renewable energy integration potential per country. Adding energy demand forecast provides with a double-sided tool to estimate actual urban energy and its future in Europe.
The European database for buildings forms and energy systems, Tabula, has just been finalized [9], making this process possible and could help assess energy sustainability in Europe.

\section{PROBLEM DEFINITION}

\section{A. Scope and steps}

This study aims to compare (i) energy demand projections for present and future time horizon and (ii) renewable energy integration to European standards and targets per country, using firstly computed actual energy demand simulations. Five steps are designed to assess a global representation of urban energy in Europe, chronologically:

- Collect climatic data

- Simulate and analyze energy demand

- Analyze and optimize energy systems

- Evaluate price reduction impact

- Compliance with EU goals

B. Main asumptions

To carry out this study, two multi-family houses of five floors are chosen as representative of city centers based on typical archetypes that compose inner urban areas of large cities. Building envelopes are adapted to match historical thermal characteristics for present time simulation and retrofitting state for the 2050 timeframe. On Tabula, this decision lead to select attributes of the oldest multi-family house, latter updated to the usual refurbishment state. Climate projection follows Swiss "Office Fédéral de Météorologie et de Climatologie MéteoSuisse" [10] A1B scenario, establishing a growth of greenhouse effect gases until 2050, followed by a slight decline. This scenario presents the closest temperature rise to the main target of Paris agreement $\left(2^{\circ} \mathrm{C}\right)$ - the further objective of $1.5^{\circ} \mathrm{C}$ being today highly questionable - and is selected as the representative climatic scenario. For renewable energy integration, an Energy Hub system is modeled and results are then compared to the Renewable Energy Directive 2020 targets [11].

\section{MethodOLOGY AND ToOLS}

\section{A. Overview}

Assessing a comparative energy demand study and renewable energy integration on the European level is difficult as no 
single software or single database allows a direct analysis. A computational platform has thus been developed to meet the requirements of this study, in which each software plays a unique role (Figure 1).

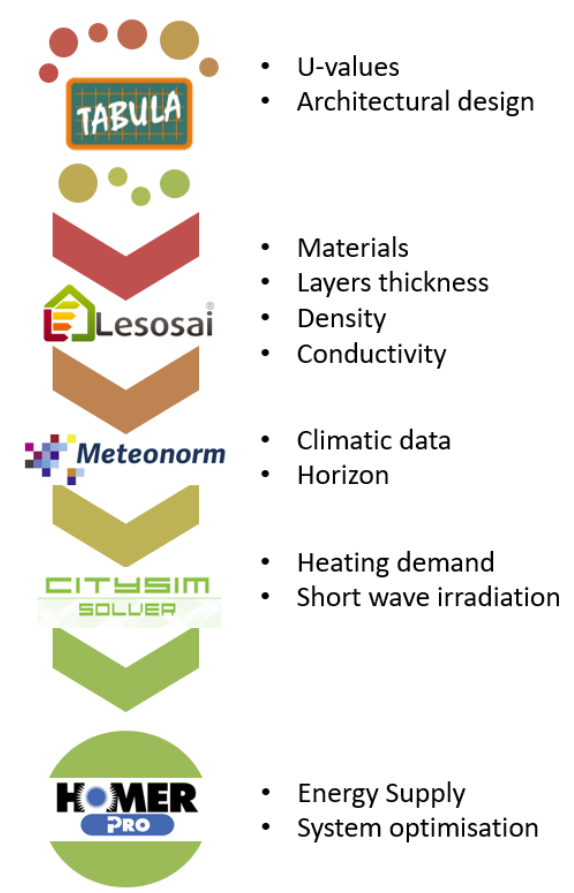

Fig. 1. Chart flow of the global methodology, in chronological order.

Firstly, building data - architectural design and U-values have been collected on Tabula for each multi-family house per country. This information is secondly transformed through the software Lesosai [12], which defines materials layers, thickness, conductivity, density and heat capacity for each component of the house: floor, roof, walls and windows. An empirical process is used to match Tabula building specifications and Lesosai materials. The physical characteristics of the dwelling are implemented in a 3D building model proper to each country. Thirdly, climatic data and horizon file of every European capital are gathered by means of the software Meteonorm [13]. Fourthly, the hourly profile of the energy demand is computed through CitySim software [14]. The same process is applied for 2050 energy projections, where the usual refurbishment state offered in Tabula is selected as the representative future of thermal characteristics and assuming A1B climatic scenario on Meteonorm. Given the energy demand results for present time and 2050 horizon, a first ad-hoc energy demand comparative analysis is made possible. Renewable energies integration and optimization of the energy supply is assessed through the software Homer based on the present hourly energy demand computed in CitySim and a nationally modified electrical load. Theses optimization are carried for present time only as representative of the actual energy transition.

\section{B. Energy demand simulation}

CitySim is a decision support tool for urban energy planners and stakeholders, here to help reducing environmental impact of buildings by either improving renewable energy use or reducing carbon emissions gases. It uses several thermal zones resistance capacity models to provide hourly energy demand profiles of imported dwellings. Interactions between buildings are taken in consideration through an algorithm of shadowing and radiation effects. CitySim requires climatic data (temperature, precipitation, horizontal diffuse and direct radiation, relative humidity, wind speed and direction, cloud cover fraction), geographic data (horizon topographical description), the 3D building model (space arrangement, thermal properties for walls, roof, floor and windows, openings, glazing ratio, energy systems) and the occupancy building pattern description, which can be obtained from the Swiss norms SIA 2024. No cooling system is modelled in this study. The final energy demand comprises the simulated heating demand and the electrical demand, modelled building on the Swiss norms SIA 2024 and later on converted for every country based on the national share of final energy consumption in the residential sector by type of end-use [15].

\section{Energy supply simulation}

To comply with hourly demand calculated via CitySim, energy supply is modelled through the microgrid software called Homer - abbreviated for Hybrid Optimization Model for Multiple Energy Resources. The concept of Energy Hub applied combines decentralized energy systems and suitable renewable sources in a bid to efficiently optimize the energy supply (Figure 2).

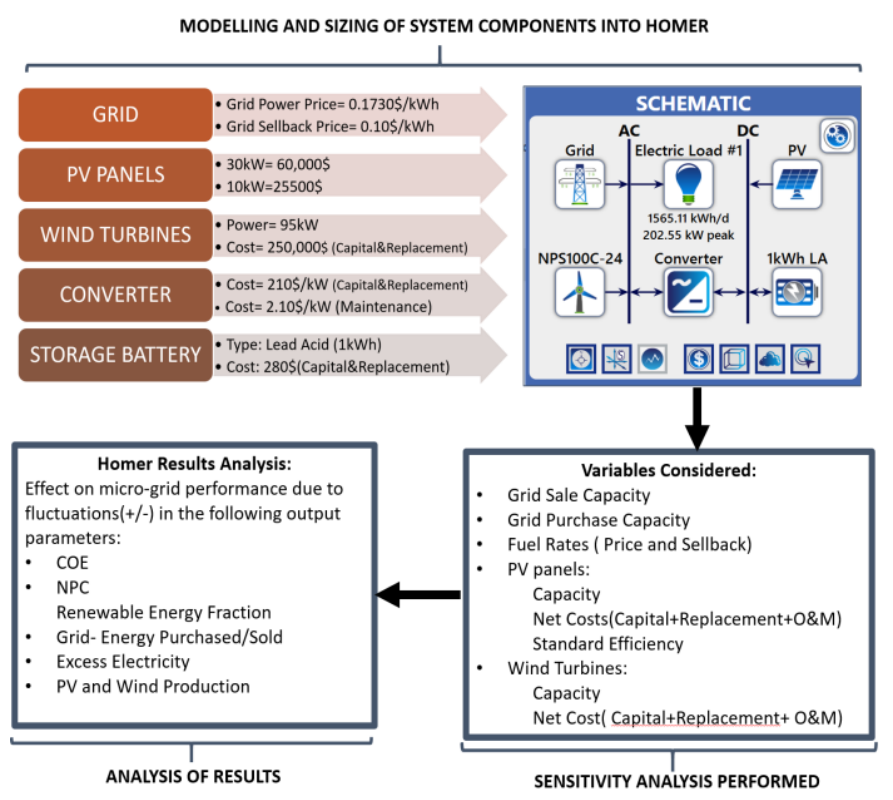

Fig. 2. Schematic of the micro-grid designed for simulations in Homer

The main criteria behind using the Energy Hub concept is to comply with the EU goals and reduce the dependence on 
conventional sources of energy by utilizing renewable energy sources in a cost-effective manner without causing environmental degradation, by minimizing carbon dioxide emissions. For the purpose of improving the share of renewable sources towards energy generation, this study primarily focuses on wind power generation using wind turbines and solar power generation using flat plate PV panels.

This model of Energy Hub shows that in addition to using conventional energy supply from the grid, renewable sources particularly PV panels and wind turbines can also be used to effectively produce electricity and therefore be utilized to meet a certain part of the demand. However, due to the nondispatchable and stochastic nature of renewable energy production, several lead acid batteries are also employed that are utilized during periods of climatic fluctuations when the renewable sources are unable to produce electricity meeting the current demand. Based on the net energy demand computed through CitySim, the simulations were conducted for the major cities of ten European countries in Homer that aimed to enhance the overall efficiency of the micro-grid system modelled for each country and maximize the net renewable energy fraction under realistic conditions. To achieve this, special focus revolved around the following output parameters:

- $\quad$ Net Present Cost (NPC)

- Cost of Energy (COE)

- Renewable Energy Fraction (Ren Frac \%)

- Grid Purchases

- Grid Sales

The sensitivity variables or input parameters considered for simulations included Grid Sale Capacity, Grid Purchase Price, Net Grid Purchase Limit, Annual Grid Purchase Capacity, and PV Panel Efficiency. The net present cost is used to estimate the total life cycle cost of the system. It takes into account all the various revenues, investments and costs that occur during the lifetime of the system and reduces into a single lump sum in year-zero dollars whereas the cash flows in the future are discounted back to year zero with the help of discount rate. The various costs that are taken into account include capital and replacement costs of the components as well as their operating and maintenance costs and costs involving grid electricity purchases. Revenues are calculated from the income generated by selling power back to the grid along with the salvage value of system equipment at their end of life. While simulating, HOMER uses the net present cost to rank different system combinations in the output section [16]. The renewable energy fraction (frem) pertaining to the micro-grid is calculated using the following equation [17]:

$$
\sum_{t=1}^{8760} f_{\text {ren }}=1-\sum_{t=1}^{8760} \frac{E_{\text {nonren }}}{E_{\text {served }}}
$$

where $E_{\text {nonren }}$ is the Nonrenewable Electricity Production $(\mathrm{kWh} / \mathrm{yr})$ and $E_{\text {served }}$ is the Net Electricity Served by the Grid (includes grid sales). The sale capacity of the grid refers to the maximum amount of energy that can be sold back to the grid in each time step [18]. The Net Grid Purchase Limit refers to the maximum value of net grid purchases less the grid sales allowed to the micro-grid [19] and the annual purchase capacity is defined as the maximum power that can be purchased from the grid in each time step [18]. The levelized cost of Electricity (COE), as defined by Homer, is the average cost per $\mathrm{kWh}$ of useful electrical energy produced by the system [20]. It is defined as follows:

$$
C O E=\frac{C_{\text {ann, tot }}}{E_{\text {served }}}
$$

where $C_{a n n, t o t}$ is the total annualized cost of the system ( $\left.\$ / y r\right)$. The power generated by the PV array is calculated by the following equation [21]:

$$
P_{P V}=Y_{P V} \cdot x_{P V}\left(\frac{G_{T}}{G_{T, S T C}}\right)\left[1+\theta\left(T_{C}-T_{C, S T C}\right)\right.
$$

where $\mathrm{Y}_{\mathrm{PV}}$ is the rated capacity of the $\mathrm{PV}$ array $(\mathrm{kWh}), x_{\mathrm{PV}}$ is the PV derating factor $(\%), \mathrm{G}_{\mathrm{T}}$ is the solar radiation incident on the PV array per time step $\left(\mathrm{kW} / \mathrm{m}^{2}\right)$. $\mathrm{G}_{\mathrm{T}, \mathrm{STC}}$ corresponds to the incident radiation at standard test conditions $(1 \mathrm{~kW} / \mathrm{m} 2), \theta$ is the temperature coefficient of power $\left(\% /{ }^{\circ} \mathrm{C}\right), \mathrm{T}_{\mathrm{C}}$ is the $\mathrm{PV}$ cell temperature in the current time step $\left({ }^{\circ} \mathrm{C}\right), \mathrm{T}_{\mathrm{C}, \mathrm{STC}}$ is the PV cell temperature under standard test conditions $\left(25^{\circ} \mathrm{C}\right)$. In order to compute the power produced by the wind turbine, Homer first calculated wind speed at the hub height of the wind turbine using the following equation [22]:

$$
U_{\text {hub }}=U_{\text {anem. }} \cdot \frac{\ln \left(z_{\text {hub }} / z_{o}\right)}{\ln \left(z_{\text {anem }} / z_{o}\right)}
$$

$\mathrm{U}_{\text {hub }}$ is the wind speed at hub height of wind turbine $(\mathrm{m} / \mathrm{s})$, $\mathrm{U}_{\text {anem }}$ is the wind speed at anemometer height $(\mathrm{m} / \mathrm{s})$, $Z_{\text {hub }}$ is the hub height of wind turbine $(\mathrm{m}), \mathrm{z}_{\text {anem }}$ is the anemometer height $(\mathrm{m})$ and $\mathrm{z}_{\mathrm{o}}$ the surface roughness length $(\mathrm{m})$.

After calculating the wind speed at the hub, the software then takes into account the wind turbine's power curve to calculate the expected power output from the wind turbine at that wind speed under standard conditions of temperature and pressure [22], as presented in Figure 3.

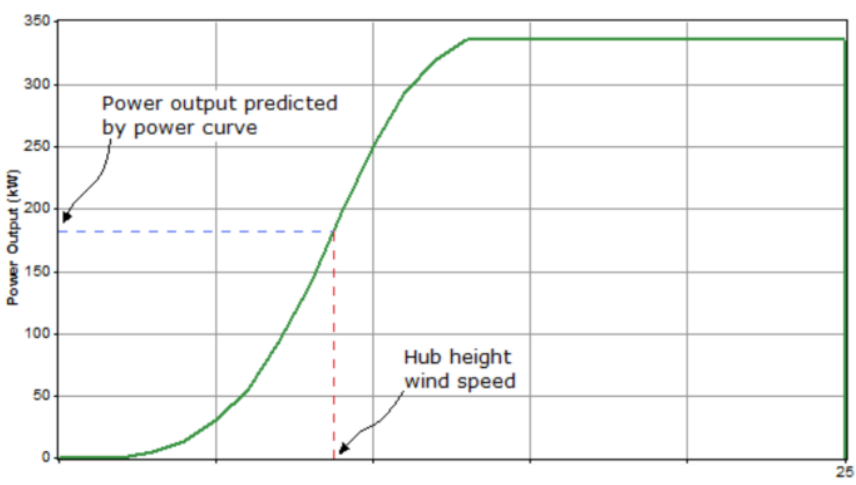

Fig. 3. Power Curve for a wind turbine at STP [22] 
Since the power is predicted at standard test conditions, Homer makes use of the air density ratio to adjust to the actual conditions using the following equation [22]:

$$
P_{W T G}=\left(\frac{\rho}{\rho_{o}}\right) \cdot P_{W T G}, \text { STP }
$$

where $\mathrm{P}_{\mathrm{WTG}}(\mathrm{kW})$ is the wind turbine power output at actual conditions, $\mathrm{P}_{\mathrm{WTG}, \mathrm{STP}}$ corresponds to the wind turbine power output at STP $(\mathrm{kW}), \rho$ is the actual air density $\left(\mathrm{kg} / \mathrm{m}^{3}\right)$ and $\rho_{\mathrm{o}}$ is the air density at STP $\left(\mathrm{kg} / \mathrm{m}^{3}\right)$.

\section{RESULTS AND ANALYSIS}

\section{A. Energy demand}

Figures 4 and 5 show the net gross heating demand, in current and future climatic conditions. Northern countries have a higher heating demand than Southern countries due to climatic differential. On the same hand, Western countries have a lower heating demand compared to Eastern countries which can be explained by the economical gradient: Western countries historically have a heavier economical weight and have been able to prevent heating demand by refurbishment strategies over the past decades. Net gross energy demand simulations for 2050 decreased for every country compared to present time simulation. Additionally, due to the renovations strategies, the difference of heating demand is lower between the counties, from $147 \mathrm{kWh} / \mathrm{m}^{2}$ today, to $99 \mathrm{kWh} / \mathrm{m}^{2}$ in 2050 . The mean net gross energy heating in 2050 is estimated to $70.8 \mathrm{kWh} / \mathrm{m}^{2}$, representing a mean heating demand reduction of $48.75 \%$. This important decline is caused simultaneously by a refurbishment strategy and a temperature increase due to climate change. Importing Tabula net gross energy demand for usual refurbishment state $\left(78.9 \mathrm{kWh} / \mathrm{m}^{2}\right.$ on average), climate change impact over heating demand is estimated as the difference between the projections: $8.1 \mathrm{kWh} / \mathrm{m}^{2}$, or $11.44 \%$ of the 2050 simulated heating demand. Similarly, refurbishment strategy is responsible of $88.56 \%$ of heating demand downturn.

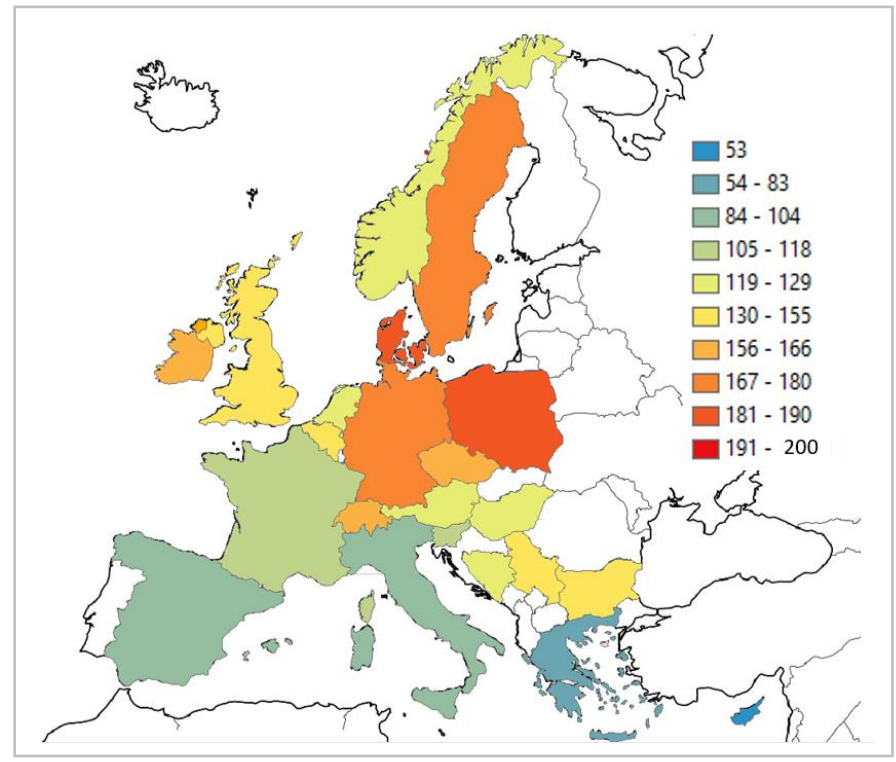

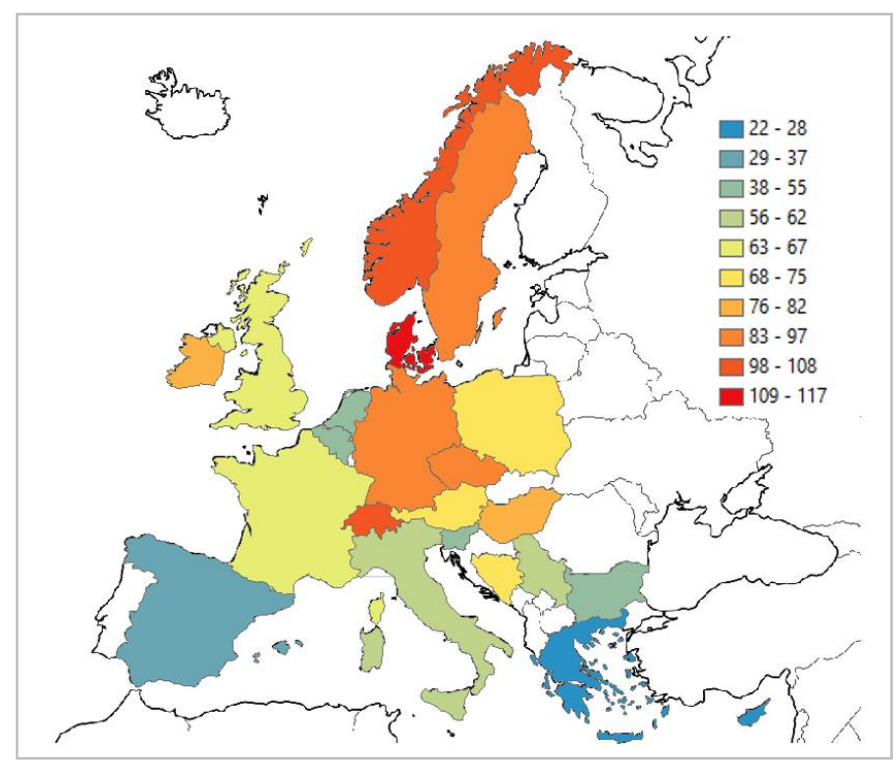

Figures 4 and 5: Net gross heating demand $\left(\mathrm{kWh} / \mathrm{m}^{2}\right)$ per country, present time (4) and 2050 simulation (5).

\section{B. Energy supply}

For the countries under study, it is imperative to define a Renewable Energy Potential that aids in measuring the attainable renewable energy penetration under realistic conditions. For this purpose, the Renewable Energy Potential (R.E.P) was defined as follows:

$$
\text { R.E.P } P_{i}=\frac{\operatorname{Re} n F r a c_{i}}{\operatorname{Re} n F r a c \text { Max }}
$$

where R.E.P $P_{i}$ is the R.E.P for country $i$, RenFrac ${ }_{i}$ is the Renewable Energy Fraction obtained for country i under sale capacity of 50\% peak load and Net Grid Purchase Limit set to $50 \%$ yearly demand. RenFrac ${ }_{\text {Max }}$ is the Maximum Renewable Energy Fraction obtained among all countries at sale capacity of 50\% peak load and Net Grid Purchase Limit of 50\% yearly demand. The R.E.P ranges between 0 and 1 with higher R.E.P value indicating higher potential for renewable energy integration. However, it was also necessary to define a Cost Index (C.I) which compares the net costs involved in attaining the R.E.P for various countries. The Cost Index (C.I) is defined as follows:

$$
C . I_{i}=\frac{N P C_{i}}{N P C_{M a x}}
$$

where C.Ii is the Cost Index (C.I) for country i, NPCi is the Net Present Cost of the System for country i at sale capacity of $50 \%$ peak load and Net Grid Purchase Limit set to 50\% yearly demand. NPCMax is the Maximum value of the Net Present Cost among all countries at sale capacity of $50 \%$ peak load and Net Grid Purchase Limit set to 50\% yearly demand. The 
C.I values are calculated for all the countries under study. A higher value of C.I implies higher costs involved in integrating renewable energy into the country. Therefore, a higher C.I value imposes greater barriers for implementing renewable energies which is not considered desirable. Combining the R.E.P and C.I values for all the cities, as shown in Figure 6, underlines that Amsterdam has the highest R.E.P amongst the lot which can be attributed to highly effective and efficient wind power generation due to reasonably high annual average wind speeds at $7.07 \mathrm{~m} / \mathrm{s}$. Cities like Budapest witnessed fairly low R.E.P which can be attributed to comparatively less favorable climatic conditions in the region which could be seen from its average solar global horizontal irradiance at 3.38 $\mathrm{kWh} / \mathrm{m}^{2} /$ day and the average annual wind speeds was just 3.90 $\mathrm{m} / \mathrm{s}$. Paris and Amsterdam also showed the least C.I values which signifies lower restrictions and economic barriers towards integrating renewable energy generation in these regions. Since the R.E.P and C.I are indices measured relatively with each country under study, Switzerland had the highest C.I value which could be attributed to the fact that the costs of capital, installing and maintaining and replacing solar panels and wind turbines is comparatively more in Switzerland than other countries under study as Switzerland boasts a very high overall cost of living.

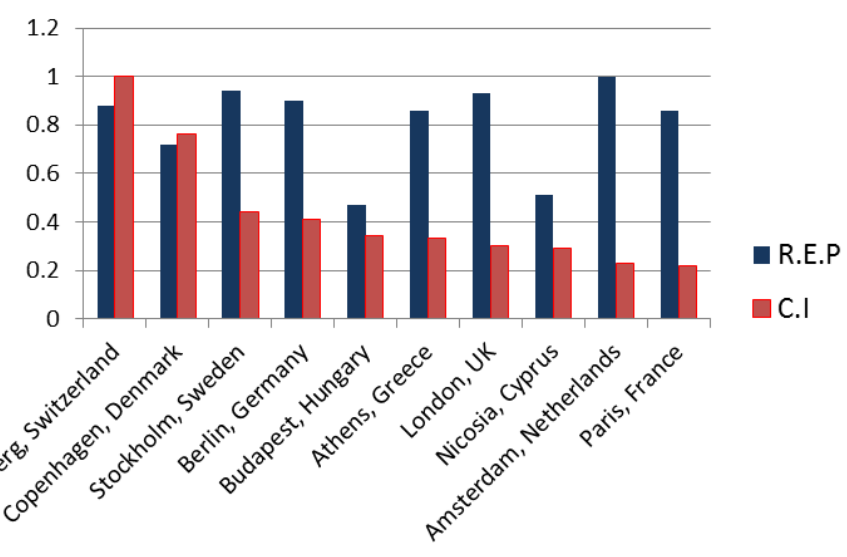

Fig. 6. Representation of R.E.P and C.I values for different European cities

\section{CONCLUSION}

Energy demand for heating is set to decrease in Europe due to global warming and refurbishment strategy. This downturn is estimated to nearly a half of today's present heating demand, as calculated by the proposed computational platform. Thanks to the proposed methodology, a database of European archetypes is defined, assuming several urban configurations and buildings properties, as function of each country. If today's present heating demand is following increasing SouthNorth and West-East paths, the future heating demand will be unevenly distributed due to differential refurbishment strategies. The close results obtained between the European web tool Tabula and the CitySim exemplify a good behavior and adaptation of the process used. Moreover, the important number of buildings present in Tabula database sets a high commitment for the basis of the method and carries in general a reliable initial data. Further development is needed to ensure a more precise modeling where an idea of city's representation is suggested by dividing inner and outer city and adding several building forms. This path would allow to set housings parameters closer to reality on top of lowering the inputs data and output results by diversification of inputs.

The integration of renewable energy is estimated to grow on fairly positive scale. Given the potential for solar and wind energy production throughout Europe coupled with increasing initiatives by the EU towards building a sustainable economy, it seems evident that the contribution of renewable energies towards total energy generation will expectedly grow and most probably exceed the targets set by the European Union. However, switching towards renewable energy production does have its own set of drawbacks. A well-balanced mix of resources essentially becomes important in order to minimize the effects of intermittency and allow for higher renewable energy market shares. Also, the cost aspects cannot be neglected when considering renewable energy production. In the present scenario, costs of installing, operating and maintaining solar panels and wind turbines by far exceed the costs of current technologies and power plants that thrive on conventional or fossil-based resources. As a result, emerging technologies should also take the cost factor into account that would help bridge this gap and make renewable energy production commercially viable and essentially profitable, consequently, generating interest and attracting more investments in the future.

\section{ACKNOWLEDGEMENTS}

This research project is financially supported by the Swiss Innovation Agency Innosuisse and is part of the Swiss Competence Center for Energy Research SCCER FEEB\&D.

\section{REFERENCES}

[1] ] Beniston M (2013) "Grand challenges in climate research". Front. Environ. Sci. 1:1. doi: 10.3389/fenvs.2013.00001

[2] United Nations, N-Habitat (2012) "Cities and climate change".

[3] United Nations, Department of Economic and Social Affairs, Population Division (2016). The World's Cities in 2016 - Data Booklet (ST/ESA/ SER.A/392).

[4] Guen, M.L., Mosca, L., Perera, A.T.D., Coccolo, S., Mohajeri, N., and Scartezzini, J.-L. (2018). Improving the energy sustainability of a Swiss village through building renovation and renewable energy integration. Energy Build. 158, 906-923

[5] Geidl, M., Koeppel, G., Favre-Perrod, P., Klockl, B., Andersson, G., and Frohlich, K. (2007). Energy hubs for the future. IEEE Power Energy Mag. 5, 24-30. 
[6] Hemmes, K., Zachariah-Wolf, J.L., Geidl, M., and Andersson, G. (2007). Towards multi-source multi-product energy systems. Int. J. Hydrog. Energy 32, 1332-1338

[7] Perera, A.T.D., Nik, V.M., Mauree, D., and Scartezzini, J.-L. (2017) Electrical hubs: An effective way to integrate non-dispatchable renewable energy sources with minimum impact to the grid. Appl. Energy 190, 232-248

[8] European Commission, "Energy 2020 A strategy for competitive, sustainable and secure energy", \{SEC(2010) 1346\}

[9] TABULA Web Tool, (n.d.), http://webtool.building-typology.eu/\#bm (Accessed 20 May 2018)

[10] Office Fédéral de Météorologie et de climatologie MéteoSuisse. "Scénarios climatiques suisse - un aperçu régional. Rapport technique n² 243 MétéoSuisse“, 2013

[11] European Commission, "Energy strategy and energy union"

[12] Lesosai http://www.lesosai.com/en/index.cfm

[13] Meteonorm http://www.meteonorm.com/

[14] Kampf J. Robinson D. "Optimisation of building form for solar energy utilisation using constrained evolutionary algorithms" , Energy and Buildings, Volume 42, Pages 807-814, 2010

[15] Eurostat (2015), "Share of final energy consumption in the residential sector by type of end-use"
[16] "Total net present cost in HOMER", HOMER Energy, 2018. [Online]. Available:

http://usersupport.homerenergy.com/customer/en/portal/articles/218725 2-total-net-present-cost-in-homer. [Accessed: 20- December- 2017].

[17] "7.133 Renewable Fraction", Homerenergy.com, 2018. [Online]. Available:https://www.homerenergy.com/products/pro/docs/3.11/_rene wable_fraction.html. [Accessed: 20- Dec- 2017].

[18] "Purchase and Sale Capacities", Homerenergy.com, 2018. [Online]. Available:https://www.homerenergy.com/products/pro/docs/3.9/purchas e_and_sale_capacities.html. [Accessed: 22- Dec- 2017].

[19] Charles Kim, "Lecture notes on Design and Simulation of Micro-Power Systems of Renewables", 2013. Washington, DC. Available at www.mwftr.com

[20] "Levelized Cost of Energy", Homerenergy.com, 2018. [Online]. Available:https://www.homerenergy.com/products/pro/docs/3.11/leveliz ed_cost_of_energy.html. [Accessed: 23- Dec- 2017].]

[21] "How HOMER Calculates the PV Array Power Output", Homerenergy.com,2018.[Online].Available:https://www.homerenergy.c om/products/pro/docs $/ 3.11 /$ how_homer_calculates_the_pv_array_power _output.html. [Accessed: 23- Dec- 2017].

[22] "How HOMER Calculates Wind Turbine Power Output", Homerenergy.com,2018.[Online].Available:https://www.homerenergy.c $\mathrm{om} /$ products/pro/docs $/ 3.11 /$ how homer calculates wind turbine power _output.html. [Accessed: 23- Dec- 2017]. 